\title{
THE IMPACT OF AIRPORT EXPERIENCE ON INTERNATIONAL TOURISTS' REVISIT INTENTION: A SOUTH AFRICAN CASE
}

\author{
Tinashe CHUCHU* \\ University of Pretoria, Faculty of Economic and Management Sciences, Department of Marketing \\ Management, Private Bag X20, Hatfield, o028, South Africa, e-mail: tinashe.chuchu@up.ac.za
}

\begin{abstract}
Citation: Tinashe CHUCHU. (2020). THE IMPACT OF AIRPORT EXPERIENCE ON INTERNATIONAL TOURISTS' REVISIT INTENTION: A SOUTH AFRICAN CASE. GeoJournal of Tourism and Geosites, 29(2), 414-427. https://doi.org/10.30892/gtg.29203-478
\end{abstract}

\begin{abstract}
Travel destinations have become more dependent on repeat commercial activities and at the center of all this trade are airports that have evolved into full service centres. Therefore, to investigate the influence that airport experience would have on travellers' intention to revisit a destination a conceptual framework was developed. The study was quantitative in nature in which data was collected through intercepts at the OR Tambo International Airport in South Africa. 503 willing international travellers participated and the collected surveys were processed in order to generate insights. To analyse the data, structural equation modelling was adopted. The main finding of the study established that conative destination image was the most influential factor in determining travellers' intention to revisit a destination. Implications emerging from the findings were presented and suggestions for further research were proposed.
\end{abstract}

Key words: tourists, airports, destination, image, servicescape

\section{INTRODUCTION}

As many destinations become more and more reliant on repeat commercial activities, the intention to revisit a destination has emerged as a paramount research area (Assaker et al., 2011). It is therefore imperative for destinations to be unique and distinguished from the competition (Sharifsamet et al., 2020). The present research focuses on destination marketing. Destination marketing is considered a phenomenon (Matlovičová \& Husárová, 2017). Marketing of a destination gradually evolves into its branding which is generally influenced by the need to attract tourists, professionals, new residents and business (Matlovičová \& Kormaníková, 2014).

According to Pike and Page (2014), destination marketing is a field that commenced in 1973. Halpern and Graham (2015) suggest that airports represent a crucial element of the transport system, as they provide travellers with essential infrastructure and facilities to transfer them from surface to air modes of transport, and

\footnotetext{
* Corresponding author
}

http://gtg.webhost.uoradea.ro/ 
facilitate airlines' arrivals and departures. Airports have recently been transformed from merely being a point of transit for visitors into extravagant attractions that provide many facilities and services (Du Plessis et al., 2014). Destination marketing cobmines business and leisure which inturn projects a positive image of (Chung et al., 2020). The aviation industry is expected to transport 16 billion passengers in 2050, and therefore airports have to develop in order to meet this growing demand for services (SuárezAlemán \& Jiménez, 2016). The traveller's satisfaction at airports has become a central issue in airport services (Suárez-Alemán \& Jiménez, 2016).

Florida et al. (2015) emphasise that airports connect places to the global economy and that airports are much more than facilities for travellers to get flights, attend in transit business meetings, or conduct duty-free shopping. Airports are a vital component of regional economic development (Florida et al., 2015). Mason (2015) postulates that tourism has become a global industry involving millions of individuals in both domestic and international travel. Destination marketing has become a highly specialised business that is constantly evolving considering that its digital component accounted for about 25\% of destination marketing budgets in 2015, but in five years' time that figure is estimated to rise to 75\% (South Africa Tourism Review, 2015).

This study was grounded in destination marketing with special focus on how tourists' experiences at the OR Tambo International Airport in Johannesburg, South Africa would influence their intention to want to revisit South Africa as a travel destination. The service scape model was partially adapted for purposes of this study. This is because customers are considered are part of the service (Eiglier \& Langeard, 1987). Previous studies on destination marketing have been conducted in various contexts. Minoli et al. (2015) researched golf tourism's sustainability, while Pike and Page (2014) conducted a review of the first 40 years of destination marketing research, in order to identify themes that have emerged from this field.

In addition, Dwyer et al. (2014) explored the return on investment of destination marketing in Australia. Furthermore, Avraham (2015) analysed the relationship between positive image and continued tourism growth, while Vogt, Jordan, et al. (2015) and Moscardo and Murphy (2016) explored small island tourism destinations.

These previous studies on destination marketing aided in identifying the gap where not much research on destination marketing had been conducted to establish whether or not traveller experiences at an airport would shape travellers' perceptions and influence their decision to revisit a destination. This research was conducted at the OR Tambo International Airport, in Johannesburg. According to Maziriri et al. (2016) Cape Town and Johannesburg are two of the most visited destinations in South Africa.

This therefore provided justification for conducting the research at the OR Tambo International Airport in Johannesburg.

\section{Problem statement}

A clearly defined research problem and a specific goal that can be achieved are the hallmarks of a good research strategy (Denscombe, 2014). This research seeks to investigate and address the challenges faced by a South African airport in attracting international tourists and retaining them based on their experiences at that airport. Motivation for investigating this problem is based on past literature that cited destination image as a challenge to modern tourism (Nicoletta \& Servidio, 2012). The study's conceptual model is provided in the following section.

\section{Conceptual model}

The study's conceptual model presented in Figure 1.

The conceptual model comprised of the predictor variables are servicescape and traveller perceived value. The mediator variables are destination image variables 
comprising of cognitive destination image, affective destination image and conative destination image. The abovementioned terms are defined in section that follows.

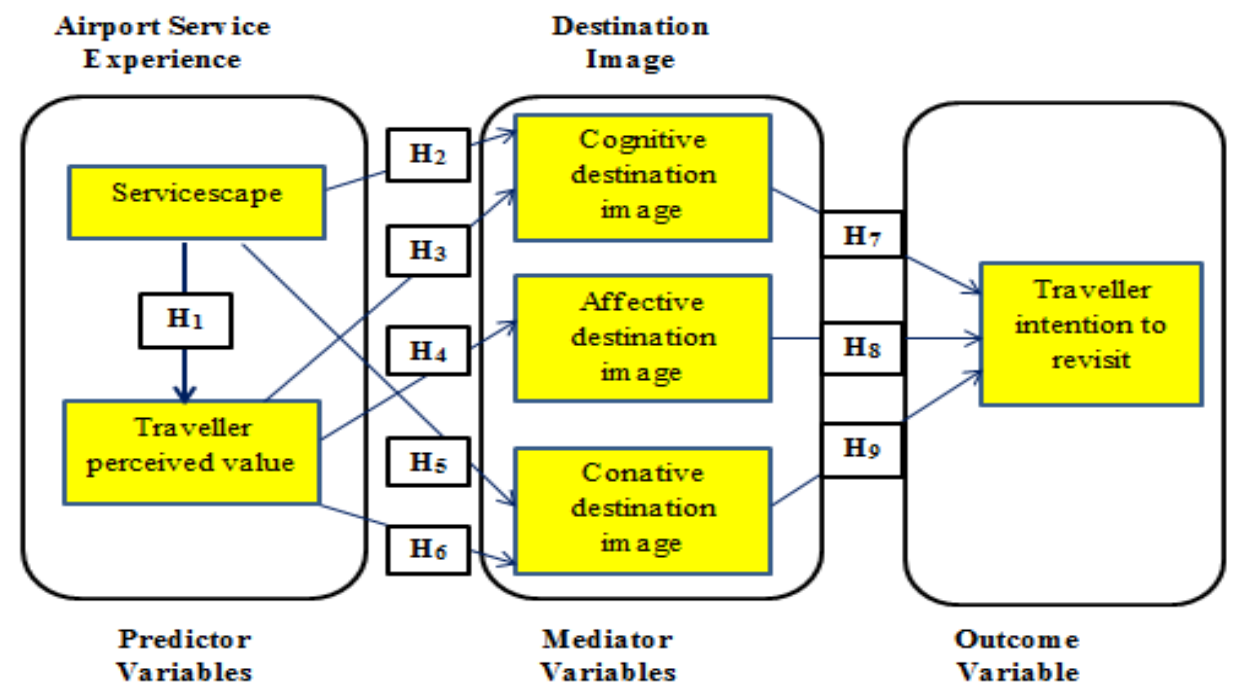

Figure 1. Conceptual model (Source: author's own work, 2020)

Table 1. Definition of variables

\begin{tabular}{|l|l|c|}
\hline \multicolumn{1}{|c|}{ VARIABLE } & \multicolumn{1}{|c|}{ DEFINITION } & SOURCE \\
\hline Servicescape & $\begin{array}{l}\text { Servicescape is commonly described as the physical } \\
\text { environment of a service company }\end{array}$ & $\begin{array}{c}\text { Balakrishnan et al., } \\
\text { (2016) }\end{array}$ \\
\hline $\begin{array}{l}\text { Travellers' } \\
\text { perceived value }\end{array}$ & $\begin{array}{l}\text { The ratio of benefits received from providers } \\
\text { relative to the costs sacrificed by travellers }\end{array}$ & $\begin{array}{c}\text { Adeola \& Adebiyi } \\
\text { (2014) }\end{array}$ \\
\hline $\begin{array}{l}\text { Cognitive } \\
\text { destination image }\end{array}$ & What potential tourists know about a destination & Chen et al., (2016) \\
\hline $\begin{array}{l}\text { Affective } \\
\text { destination image }\end{array}$ & $\begin{array}{l}\text { Feelings that potential tourists hold about a } \\
\text { destination }\end{array}$ & Chen et al.(2016) \\
\hline $\begin{array}{l}\text { Conative } \\
\text { destination image }\end{array}$ & $\begin{array}{l}\text { The manner in which an individual with any degree } \\
\text { of motivation goes about acting on that motivation }\end{array}$ & $\begin{array}{c}\text { Gerdes \& Stromwall } \\
\text { (2008) }\end{array}$ \\
\hline $\begin{array}{l}\text { Traveller intention } \\
\text { to revisit }\end{array}$ & $\begin{array}{l}\text { An individual's willingness to make a repeat visit to } \\
\text { the same destination }\end{array}$ & Stylos et al., (2016) \\
\hline
\end{tabular}

SOUTH AFRICAN TOURISM, DESTINATION IMAGE AND AIRPORT EXPERIENCE

Tourism has shown significant growth progress and is estimated to reach 1.8 billion international travellers by 2030 (World Tourism Organisation, 2011; Law et al., 2016). The tourism industry and organisations within it seek to understand the needs of tourists because they depend on such information to make strategic decisions, such as where their businesses should be situated (Josiassen et al., 2015). It is a service sector, with most parts of the tourism value chain comprising an experience, not the purchase of a physical product or item (South Africa Tourism Review, 2015). According to Lopes (2011), tourism has grown to become one of the foremost sectors of the world economy. Tourism makes a makes significant contribution to the global domestic product, jobs, and foreign exchange earnings (South Africa Tourism Review, 2015). It is not a typical economic sector, and challenges conventional conceptions of how production and consumption take place (South Africa Tourism Review, 2015). 
The growth and impact of tourism has provided destinations around the world with numerous advantages, such as employment for residents and an increase in GDP/economic development (VisitBritain, 2014; Deloitte, 2013; Pyke et al., 2016). Within the context of the present research, destination image is made up of cognitive destination image, affective destination image and cognitive destination image. According to Matos et al. (2012) destination image is the product of the knowledge the tourist acquired about the destination (cognitive component), the feelings or attachment the tourist develops towards a destination (affective) and his or her intention or actions in the future (conative). Destination image as a construct is influenced by servicescape (Lin, 2004) and traveller perceived value (Chen \& Tsai, 2007).

Tourism is considered key to South Africa's economy (Statistics South Africa, 2016).The tourism industry in Africa receives a considerable amount of attention from policy makers and South Africa is Africa's leading tourism destination (Visser \& Hoogendoom, 2011). Tourism marketing strategies can have substantial implications in terms of the social development of tourist destinations, and the opportunities and limitations for stakeholders to engage in tourism (Jeuring, 2015). Tourism marketing as a policy tool, aims to influence representations of tourism destinations (Cousin, 2008; Kavaratzis, 2012; Jeuring, 2015). Domestic tourists contributed 57\% (R124,7 billion) of total tourism spend in 2013, while international tourists contributed 43\% (R94,2 billion) (South Africa Tourism Review, 2015). Airports have developed over the past decades from being merely basic terminals that function as points of transit, into complicated market facilities providing multiple services (Jarach, 2001; Martin-Cejas, 2006; Du Plessis, Saayman \& Potgieter, 2014). Due to the subsequent commercialisation and privatisation of many airports in recent years, airport management organisations have invested immensely in the marketing and branding of airports (Castro \& Lohmann, 2014).

\section{HYPOTHESES DEVELOPMENT}

\section{Servicescape and traveller perceived value}

This hypothesis is derived from the concept of services. Rajesh (2013) suggested that servicescape, more specifically shopping, dining environment and attractions had an impact on the intention to revisit a destination. However Rajesh (2013) further argued that shopping environment had no directly influence on revisit on intention to revisit a destination but it was through satisfaction of the tourist. Siu et al. (2012) suggest that servicescape is linked to customer perceived value through positive affective customer responses and satisfaction. Bogicevic et al. (2013) found that in the airport environment servicescape features such as scent and design positively influence the traveller enjoyment in that airport. Product quality and service quality service are antecedents customer perceived value (Davidson et al. 2015). Therefore, inferring from the literature and the empirical evidence mentioned above, the study therefore hypothesised that:

H1: Servicescape is directly and positively related to traveller perceived value.

\section{Servicescape and cognitive destination image}

Similar to hypothesis 1 (H1), this hypothesis is also developed from the concept of services. Past studies have shown that physical environment, also referred to as servicescape plays a crucial role both positive and negative, in customers' impression formation (Bitner, 1992; Lin, 2004). According to Lin (2004) servicescape is related to cognitive images however this relationship is moderated by the micro-perspective (personality traits, expectations, goal behaviours and cognitive-style involvement) and the macro-perspective (socio-cultural, individualism vs collectivism and demographics). Lin (2004) stated that servicescape positively influences cognitive processing (organize 
perceptual image) while affective processing (emotions) are directly and positively related to cognitive processing and in-turn cognitive processing affects behaviour.

According to Bitner (1992) services scape is indirectly associated with cognitive beliefs through customer and employee actions. However a later source (Ryu et al., 2012) postulated that a firm's servicescape has a direct relationship with cognitive responses, such as customer beliefs and perceptions.

H2: Servicescape is directly and positively related to cognitive destination image.

Traveller perceived value and cognitive destination image

According to Sylos et al. (2016) destination images, holistic images and personal normative beliefs are predictors of intention to revisit a destination. Destination image theory is the theory that provided a basis for the relationship that existed between traveller perceived value and cognitive destination image was. Authors such as Assaker (2014) explored destination image in great detail. According to Assaker (2014) destination image is a multi-construct theory that comprises of cognitive, affective and conative elements. In addition Castellanos-Verdugo et al. (2016) pointed out that comprehension of the drivers of the perceived value of a destination is imperative.

Customer perceived value is viewed as a cognitive construct since it is determined through a cognitive exchange between quality and sacrifice (Ryu et al., 2012). According to Pike and Bianchi (2016) perceived value is positively related to satisfaction and loyalty. Therefore, inferring from the literature and the empirical evidence mentioned above, the study hypothesised the following statements:

H3: Traveller perceived value is directly and positively related to cognitive destination image.

\section{Traveller perceived value and affective destination image}

Hsu (2008) suggests that value perceptions are influenced by expectations and perceived quality. Hsu (2008) further added that those value perceptions in turn influence satisfaction. Additionally, Mohammed et al. (2014) posited that affective destination image directly and positively influences tourist behavioural intention.

Similar to the previously stated hypothesis (traveller perceived value and cognitive destination image) the theory that also forms the basis for the relationship between traveller perceived value and affective destination image is the destination image theory (Sylos et al., 2016). According to Xie and Lee (2013) affective image refers to the traveller's evaluation of the emotional quality of feeling regarding features of the surrounding environment. Furthermore Xie and Lee (2013) implied that traveller perceived value was therefore related to affective destination image.

Therefore, deducing from the literature and the empirical evidence mentioned above, the study hypothesises the following statements:

H4: Traveller perceived value is directly and positively related to affective destination image.

\section{Servicescape and conative destination image}

Shopping environment, accessibility to facilities and relaxation all have an influence on the destination image as well as destination loyalty (Rajesh, 2013). Han et al. (2011) argued that service quality and satisfaction have an influence on conative image. Sylos et al. (2016) suggested that the destination image theory is associated to the relationship that exists between conative destination image and servicescape. Wang et al. (2011) established that conative outcomes can be significantly triggered by stimuli from a pleasant environment. Sung et al. (2011) suggested that conative destination image is closely associated with the services that travellers receive as far as tourism research is concerned. 
This therefore makes this relationship important and relevant for the study. Therefore, inferring from the literature and the empirical evidence mentioned above, the study hypothesised the following statement:

$\mathrm{H}_{5}$ : Servicescape is directly and positively related to conative destination image.

\section{Traveller perceived value and conative destination image}

Hyun and O'Keefe (2012) provide the rational for the hypothesis in question as they posited that the destination image theory is a well-established research area among both tourism marketers and travellers. The destination concept is the theory that is most closely associated with the relationship that exists between traveller perceived value and conative destination image. Destination image is a shared system of thoughts, opinions, feelings, conceptions, and intentions toward a destination" which not only identifies the multiplicity of elements (cognitive, affective, and conative) but also their influence on the purchase decision process (Prayag \& Ryan, 2012). Rajesh (2013) stated that traveller influence has an impact on destination image. The success of destinations primarily relies on experiential qualities of their offerings (Hosany \& Gilbert, 2010). Customer perceived value is positively associated service quality attributes with was a notion (e.g., tangibles, empathy, reliability, and responsiveness) (Eggert \& Ulaga, 2002; Ryu et al., 2012). Therefore, deducing from the literature and the empirical evidence mentioned above, the study hypothesised the statement below:

H6: Traveller perceived value is directly and positively related to conative destination image.

\section{Cognitive destination image and traveller intention to revisit}

The justification for this hypothesis is founded on the destination image theory (Hyun \& O'Keefe, 2012). The cognitive or perceptual components are concerned with the beliefs or knowledge about a destination's features evaluations (Stepchenkova \& Mills, 2010). The present study hypothesised that cognitive destination image was directly and positively associated with traveller intention to revisit a destination.

Additionally Park et al. (2016) also observed that there was an alternate option in which destination image and traveller intention were mediated by traveller constraints in which this became a negative linkage. The likelihood of tourists to make future visits then ultimately leads to the likelihood of recommendation for that destination (Eusébio \& Vieira, 2013). Therefore, inferring from the literature and the empirical evidence mentioned above, the study hypothesised the following statements:

H7: Cognitive destination image is directly and positively related to traveller intention to revisit.

\section{Affective destination image and traveller intention to revisit}

In a recent study that that investigated the relationship between affective destination image and traveller intention to revisit (Stylos et al., 2016) found a link between these two constructs. Affective image positively influences traveller intention according to (Chen et al., 2016). Stylos et al. (2016) posited that affective image directly and positively influences a tourist's intention to revisit a destination. Affective image is positively related to the intention to recommend the destination to other travellers $(\mathrm{Qu}$ et al., 2011). However, this is not a direct relationship as it is mediated through the overall image that the traveller has of the destination. Therefore, inferring from the literature and the empirical evidence mentioned above, the study hypothesised that:

H8: Affective destination image is directly and positively related to traveller intention to revisit. 


\section{Conative destination image and traveller intention to revisit}

According to Stylos et al. (2016) conative destination image influences traveller intention to revisit significantly in two ways, first directly and second indirectly through holistic image Stylos et al. (2016) further argued that as far as the relationship between conative destination image and holistic image is concerned personal normative belief is involved. Li et al. (2016) further argued that tourists' overall image is significantly and positively related to their conative image. However Ekinci et al. (2007) suggested that the image of the host (destination) has a positive effect on visitor intention to return. Therefore, inferring from the literature and the empirical evidence mentioned above, the study hypothesised the following statements:

H9: Conative destination image is directly and positively related to traveller intention to revisit.

\section{METHODOLOGY}

A positivist approach was adopted as it was imperative to obtain objective findings. The study was quantitative in nature where 508 surveys where administered to willing international tourists at the OR Tambo International Airport in South Africa.

Of the 508 surveys, 503 were useable for data analysis purposes. The primary data for the research was collected in 2017. The respondents were selected using the convenience sampling approach due to the absence of a sampling frame of tourists that passed through this particular airport. After research data was collected from the participants it was analysed using SPSS 24 and AMOS 24 software. Reliability, validity and model fit checks were conducted in SPSS 24 to establish its suitability for analysis purposes. Structural equation modeling was carried-out in AMOS 24 adopting a twostage approach that involved confirmatory factor analysis followed by hypotheses testing in order to test proposed relationships. Descriptive statistics were conducted using SPSS24 in order to provide an illustration of the sample's profile.

\section{RESEARCH ANALYSIS AND INTERPRETATION \\ Measurement model assessment}

As part of assessing the reliability of the measurements, model fit was checked. The outcomes are presented in table 2 below.

Table 2. Model fit indices

\begin{tabular}{|c|c|c|c|c|c|c|c|}
\hline CMIN/DF & GFI & NFI & RFI & IFI & TLI & CFI & RMSEA \\
\hline 1,690 & 0,901 & 0,922 & 0,904 & 0,967 & 0,958 & 0,966 & 0,037 \\
\hline
\end{tabular}

CFA Model: Confirmatory factor analysis model; CMIN/DF: Chi-square; GFI: Goodness of fit index; NFI: Normed Fit index; RFI; Relative Fit Index; IFI: Incremental Fit Index; TLI: Tucker Lewis Index; CFI: Comparative Fit Index. RMSEA: Root Measure Standard Error Approximation

Confirmatory factor analysis and structural modeling were conducted in two stages where the first stage was an assessment of model fit and the second stage was the testing of the proposed conceptual model. As for model fit the following indices were assessed: chi-square (CMIN/DF), goodness of fit index (GFI), Normed Fit index (NFI), Relative Fit Index (RFI), Incremental Fit Index (IFI), Tucker Lewis Index (TLI), Comparative Fit Index (CFI) Root Measure Standard Error Approximation (RMSEA). Table 2 below presents the model fit indices. The Chi-square (CMIN/DF) was 1.690, falling below the recommended threshold of 3 . The rest of the model fit indices were as follows: The Comparative fit index (CFI) was 0.966 exceeded the acceptable level of 0.900 suggested by (Hooper et al., 2008), the goodness of fit index (GFI) was 0.901 exceeding the acceptable 
0.9 level according to (Baumgartner \& Hombur, 1996). The Relative fit index (RFI) was 0.904 also exceeding recommend value of 0.9 by (McDonald \& Ho, 2002). The following section presents the study's accuracy and descriptive statistics.

The mean values for the constructs presented and defined in Table 1 ranged from 5 to 4 and since there were within close range to each other it could be assumed that the respondents were fairly spread. The standard deviation values ranged from -2 to +2 thereby also revealing fair distribution of respondents. The average variance extracted values were generally above the acceptable threshold of 0.5 as recommended by (Fraering \& Minor, 2006) with the exception of cognitive destination image (CGDI) which had 0.457 , however this value was kept in the study as the variable was material to the research considering that destination image was the mediator for the conceptual model and could not be removed. Further research might possibly explain why CGDI slightly fell short of the recommended threshold of 0.5 . In terms of reliability the Cronbach's alpha values were above 0.6 as recommended by literature (Dusick, 2011). The composite reliability values were above 0.7 , meeting the threshold suggested by Hair et al. (2006) respectively. The highest shared value of each construct was lower than the corresponding average variance extracted value for the same variable therefore proving the existence of discriminate validity according to (Nusair \& Hua, 2010). However, CNDI was the exception were the highest shared variance was slightly higher than the average variance extracted value. The sample profile is presented in Table 3 where gender, age and purpose of the trip were explored. Thereafter, more advanced statistics were conducted namely presentation of the structural model and hypotheses testing.

Table 3. Tourist profile

\begin{tabular}{|l|c|}
\hline Gender & Percentage \\
\hline Male & $58 \%$ \\
\hline Female & $39 \%$ \\
\hline Preferred not to state & $3 \%$ \\
\hline Total & $\mathbf{1 0 0 \%}$ \\
\hline Age & Percentage \\
\hline $18-19$ & $7 \%$ \\
\hline $20-25$ & $\mathbf{2 2} \%$ \\
\hline $26-35$ & $32 \%$ \\
\hline $36+$ & $38 \%$ \\
\hline Total & $\mathbf{1 0 0 \%}$ \\
\hline Purpose of Trip & Percentage \\
\hline Leisure & $35 \%$ \\
\hline Business & $33 \%$ \\
\hline Educational purpose & $17 \%$ \\
\hline Medical purposes & $\mathbf{2 \%}$ \\
\hline Other & $\mathbf{1 2 \%}$ \\
\hline No response & $\mathbf{1} \%$ \\
\hline Not applicable & $0 \%$ \\
\hline
\end{tabular}

The section above was a presentation of the profile of the tourists who participated in the study. It could be observed that males represented more than half of all respondents indicated by $58 \%$, while females only accounted for $39 \%$. The remainder, $3 \%$ were those that refused to state their gender. As for the age groups of the tourists that participated it was observed that those aged 36 and older had the highest representation at $38 \%$, followed by those that were 26 to 35 , at $32 \%$, while those that ranged from 20 to 25 accounted for $22 \%$ of all participants. The smallest age group was 
that of the 18 to 19 age group representing 7\%. Most tourists visited South Africa for leisure, indicated by $35 \%$, followed by business travellers (33\%), educational purpose travellers (17\%), medical purpose travellers (2\%), other travellers (12\%). The last groups in terms of representation were those that did not provide a response as well as those that that stated that it was not applicable to respond to a question on "purpose of trip." The following section was provided the structural model in Figure 2 (based on proposed hypothesis). Later on, the findings of the hypothesis were presented in Table 4.

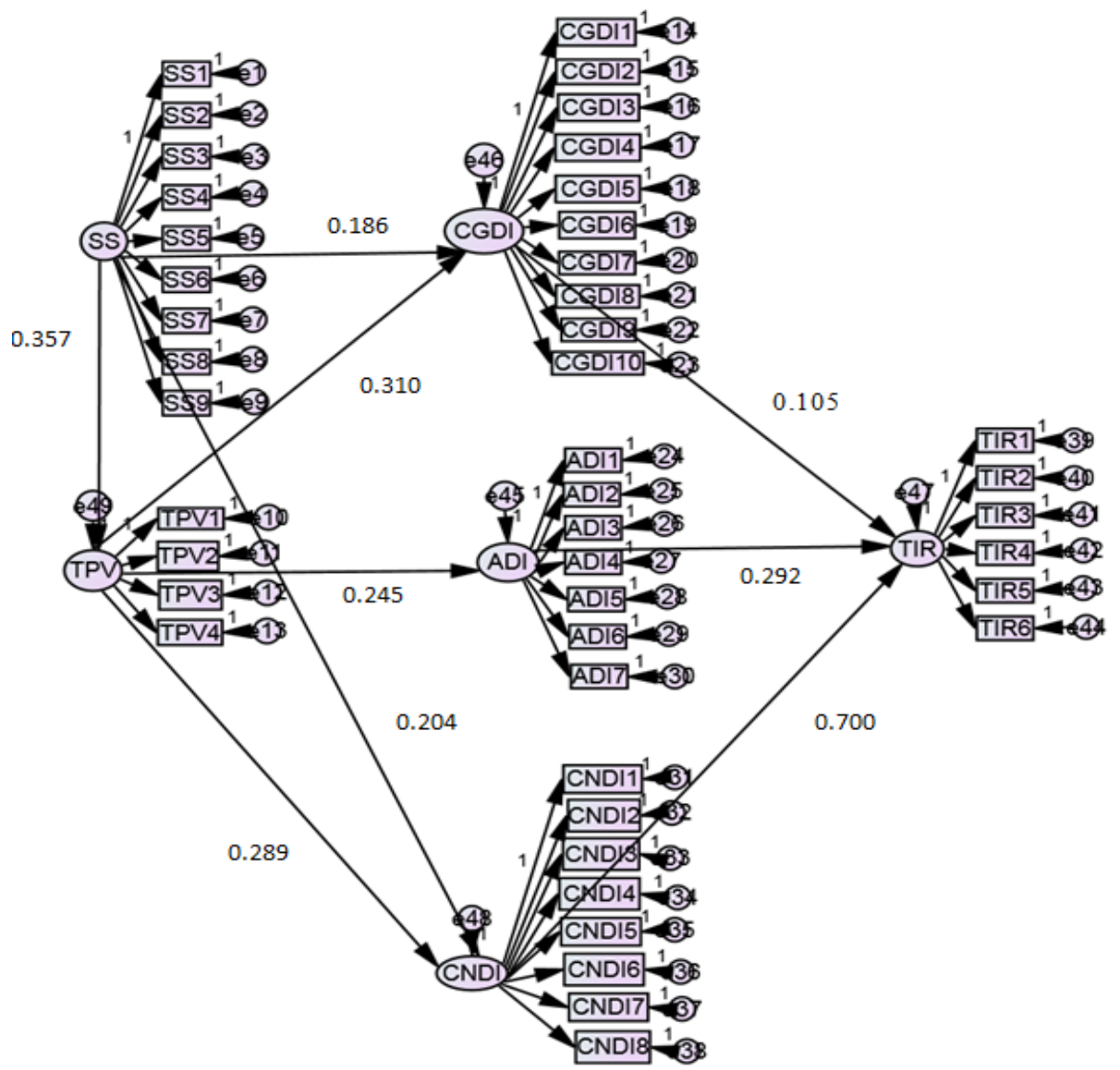

Figure 2. Structural model (Source: author's own work, 2020)

Key: SS: Servicescape, TPV: Traveller perceived value, CGDI: Cognitive destination image, ADI: Affective Destination, CNDI: Conative destination image, TIR: Traveller intention to revisit

The following section presents Table 4, which shows the testing of the proposed hypothesis of the study. Path coefficient values, p-values and their outcomes are presented followed by a series of discussions.

\section{Discussion of results}

It was observed after data analysis that all proposed hypotheses with the exception of $\left(\mathrm{H}_{7}\right)$ were both significant and supported. $\mathrm{H}_{7}$ (cognitive destination image and traveller intention to revisit). Conative destination image and traveller intention to revisit was observed to have the strongest relationship. This suggested that tourists at the airport were 
mainly influenced by pre-conceived images of the destination in terms of their willingness to revisit. Additionally this meant that their perception of the image presented by the destination on arrival (airport) did not do much in persuading them to revisit the destination. Cognitive destination image and traveller intention to revisit in addition to being the only hypothesis not supported was also the weakest of all proposed hypotheses.

Table 4. Hypotheses results

\begin{tabular}{|l|c|c|c|}
\hline \multicolumn{1}{|c|}{ Hypothesis } & Path Coefficient & P-Value & Outcome \\
\hline $\begin{array}{l}\text { Servicescape (SS) and Traveller perceived } \\
\text { value (TPV) }\end{array}$ & 0.357 & $* * *$ & $\begin{array}{c}\text { Supported and } \\
\text { Significant }\end{array}$ \\
\hline $\begin{array}{l}\text { Servicescape (SS) and cognitive } \\
\text { destination Image (CGDI) }\end{array}$ & 0.186 & $* * *$ & $\begin{array}{c}\text { Supported and } \\
\text { Significant }\end{array}$ \\
\hline $\begin{array}{l}\text { Traveller perceived value (TPV) and } \\
\text { cognitive destination image (CGDI) }\end{array}$ & 0.310 & $* * *$ & $\begin{array}{c}\text { Supported and } \\
\text { Significant }\end{array}$ \\
\hline $\begin{array}{l}\text { Traveller perceived value (TPV) and } \\
\text { Affective Destination Image (ADI) }\end{array}$ & 0.245 & 0.204 & $\begin{array}{c}\text { Supported and } \\
\text { Significant }\end{array}$ \\
\hline $\begin{array}{l}\text { Servicescape (SS) and Conative } \\
\text { Destination Image (CNDI) }\end{array}$ & 0.289 & $\begin{array}{c}\text { Supported and } \\
\text { Significant }\end{array}$ \\
\hline $\begin{array}{l}\text { Traveller perceived value (TPV) and } \\
\text { Conative Destination Image (CNDI) }\end{array}$ & 0.105 & $\begin{array}{c}\text { Supported and } \\
\text { Significant }\end{array}$ \\
\hline $\begin{array}{l}\text { Cognitive Destination Image (CGDI) and } \\
\text { Traveller Intention to Revisit (TIR) }\end{array}$ & 0.292 & $\begin{array}{l}\text { Supported but } \\
\text { not Significant }\end{array}$ \\
\hline $\begin{array}{l}\text { Affective Destination Image (ADI) and } \\
\text { Traveller Intention to Revisit (TIR) }\end{array}$ & 0.700 & $\begin{array}{c}\text { Supported and } \\
\text { Significant }\end{array}$ \\
\hline $\begin{array}{l}\text { Conative Destination Image (CNDI) and } \\
\text { Traveller Intention to Revisit (TIR) }\end{array}$ & & $\begin{array}{c}\text { Supported and } \\
\text { Significant }\end{array}$ \\
\hline
\end{tabular}

Servicescape and Traveller perceived value have a path coefficient of 0.357 . This relationship was both supported and significant at ( $p$ value $<0.001$ ) similar to the proposed hypothesis. This outcome suggested airport servicescape positively and directly influenced traveller perceived value. Travellers perceived the airport's physically environment as positively enhancing the experience at the airport and providing the impression that the services brought value for their money. Servicescape and Traveller perceived value a path coefficient of 0.186 . This relationship was both supported and significant at ( $\mathrm{p}$ value $<0.001)$. This result was in line with the proposed hypothesis. This outcome suggested airport servicescape positively and directly cognitive destination image. This result implied that what traveller thought about the destination's image (CGDI) was positively influenced by the airport's physical environment servicescape.

Traveller perceived value was found to have a positive and direct impact on cognitive image in line with the hypothesis. This relationship was both supported and significant at ( $p$ value < o.001) having a path coefficient of 0.310 . This coutcome is supported by Chuchu (2019), who established that cognitive destination image was influenced by the traveller's perception of value. In addition the finding suggested the perceived value of services and products at the airport matched travellers' thoughts and expectations. This was closely associated with what those travellers thought about the destination at which these services were being provided. Traveller perceived value and affective destination image were both positively and directly associated as proposed in the hypothesis. This relationship was both supported and significant at ( $\mathrm{p}$ value $<0.001$ ) level of significance. Travellers' view of receiving value for the money matched the emotions associated with their airport experience (affective destination image). This relationship had a path coefficient of 0.204 . Airport servicescape had a positive influence on the information that travellers had regarding the image of a destination. This posited that the 
airport's surroundings had a positive contribution to what travellers already knew about a destination as proposed in the hypothesis. This relationship was both supported and significant at ( $p$ value < o.001) level of significance. The relationship had a path coefficient of 0.204 . Travellers' perception of value was seen to have a directly positive contribution to the knowledge of the image that those travellers already possessed. This relationship was consistent with the hypothesis stated in this study concerning this relationship. Furthermore, this relationship was both supported and significant at (p value $<0.001$ ) level of significance. This relationship had a path coefficient of 0.289 .

Cognitive destination image had an influence on traveller intention to revisit a destination. This relationship was also supported but not significant. Travellers' thoughts regarding a destination directly influenced their intention to revisit the destination. This relationship had a path coefficient of 0.105. It is important to note that of all the relationships this was the only not significant. Affective destination image traveller intention to revisit were both positively as well as directly associated as proposed in the hypothesis. This relationship was also both supported and significant at ( $\mathrm{p}$ value $<0.001$ ) level of significance. The emotions that traveller's associated with the destination positively contributed to their intention to revisit that destination. This relationship had a path coefficient of 0.292. Lastly, conative destination image had a direct and positive influence on traveller intention to revisit. This relationship was both supported and significant at ( $p$ value < o.001) level of significance. This relationship had a path coefficient of 0.700 . This finding suggested travellers were willing to revisit a destination based on the information they already had regarding that destination. Conative destination image was observed as having the strongest influence on travellers' intention to re-visit a destination. This finding is supported by Chung et al. (2020) who suggested that, destination marketing, if conducted properly would influence business and lesuire travellers to return to a destination with addional tourists from their home countries.

\section{CONCLUSION}

The overall implication of the study was that key players that can affect tourist experience in South Africa such as the government, tourism organisations as well airport management organisations should focus their efforts in ensuring that South Africa as a destination is portrayed positively as this was established through empirical research to as a driver of Tourism related visits to South Africa. Tourist existing knowledge of South Africa (conative destination image) became the strongest influence on their intention to revisit the country as a travel destination. This implied that it is not only necessary to ensure that tourists are afforded the best treatment at the airport and within the nation's borders but more importantly images of South Africa abroad should be positive as this helps create preconceived ideas of the country in the minds of the travellers before they even visit South Africa. The main factual conclusion was that international tourists' perceptions were based on their perceptions of what they already knew about the destination. This was because in their responses the strongest influencer of their intention to revisit the destination was conative destination image (H9).

\section{Managerial implications}

The key players that can affect tourist experience in South Africa such as the government, tourism organisations as well airport management organisations should increase efforts on ensuring that South Africa as a destination is portrayed positively in the home countries of those international visitors. The implication is that more active marketing is needed by the government and airports to marketing themselves abroad rather than within South Africa as proven by the relationship between conative destination image and traveller intention to revisit (H9). 


\section{Limitations}

The study faced certain limitations that could have led to possible bias in the findings. For instance only one airport was used therefore the participants might have not provided much diversity in responses as they were all exposed to the same environment. Another possible limitation is the academic nature of the questionnaire as this could have been a barrier to none English language native speakers.

Finally, the last potential limitation was that due to time constraints of the travellers and other external factors associated with being on a foreign country might have caused the participants to provide rushed responses.

\section{Recommendations and suggestions for future research}

Based on the findings of the study it that future researchers consider other locations other than the airport environment for instance at tourist attractions or facilities such as holiday resorts in order to establish if the results of similar results would be obtained as of this study. The reason being that it was highly plausible that the international tourists surveyed in this study also had a stay at South African holiday resorts and surveying them before they return to the airport on their way back might not have any potential biases that could be caused by anxiety or frustration at the airports. It could also be recommended that potential relationships from the conceptual model that were not analysed for purposes of this study be analysed.

For example analysing direct effects of servicescape and traveller perceived value on traveller intention to revisit a destination. In conclusion it could also be recommended for future researchers to test the exact same conceptual model and establish whether similar or different results can be obtained in comparison to those achieved in this study. Additional variables such as reputation of country/ destination or reputation of airport could be proposed in addition to the conceptual model for this research as this could potentially produce interesting findings. Possible avenues for future research are that international tourists could be approached after they have stayed in the country or destination. This would probably provide different perspectives of the research topic in question as the current research might have led to bias as the respondents were only exposed to one element of the destination being the airport.

\section{REFERENCES}

Adeola, M. M., \& Adebiyi, S. O. (2014). Service quality, perceived value and customer satisfaction as determinant of airline choice in Nigeria. International Letters of Social and Humanistic Sciences, 9: 66-80.

Assaker, G. (2014). Examining a hierarchical model of Australia's destination image. Journal of Vacation Marketing, 20(3): 195-210.

Avraham, E. (2015). Destination image repair during crisis: Attracting tourism during the Arab Spring uprisings. Tourism Management, 47: 224-232.

Balakrishnan, B. K., Muthaly, S., \& Leenders, M. (2016). Insights from Coworking Spaces as Unique Service Organizations: The Role of Physical and Social Elements. In Rediscovering the Essentiality of Marketing (pp. 837-848). Springer International Publishing.

Baumgartner, H., \& Homburg, C. (1996). Applications of structural equation modeling in marketing and consumer research: A review. International Journal of Research in Marketing, 13(2): 139-161.

Bogicevic, V., Yang, W., Bilgihan, A., \& Bujisic, M. (2013). Airport service quality drivers of passenger satisfaction. Tourism Review, 68(4): 3-18.

Castro, R., \& Lohmann, G. (2014). Airport branding: Content analysis of vision statements. Research in Transportation Business \& Management, 10: 4-14.

Chen, C. C., Lai, Y. H. R., Petrick, J. F., \& Lin, Y. H. (2016). Tourism between divided nations: An examination of stereotyping on destination image. Tourism Management, 55: 25-36.

Chen, C. F., \& Tsai, D. (2007). How destination image and evaluative factors affect behavioral intentions? Tourism management, 28(4): 1115-1122.

Chung, J. Y., Choi, Y. K., Yoo, B. K., \& Kim, S. H. (2020). Bleisure tourism experience chain: implications for destination marketing. Asia Pacific Journal of Tourism Research, 25(3), 300-310. 
Chuchu, T. (2019). Data on the Relationship between Traveller Perceived Value and Traveller Intention to Revisit a Destination. Data in Brief. 26(October), 1-6 https://doi.org/10.1016/j.dib.2019.104435.

Cousin, S. (2008). The nation state as an identifying image Traditions and stakes in tourism policy, Touraine, France. Tourist Studies, 8(2): 193-209.

Davidson M.C.G., McPhail R., \& Barry S., (2015) New Perspectives in Hospitality Management. WA. UK. Emerald Group Publishing Limited

Deloitte. (2013). Tourism: jobs and growth. The economic contribution of the tourism economy in the UK (London, United Kingdom) Retrieved from http://www.tourismni.com/globalassets/facts-andfigures/research-reports/tourism-performance-statistics/economic-impact-of-tourism/economicimpact---deloitte--tourism---jobs--growth.pdf Accessed (23/02/2017).

Denscombe, M. (2014). The good research guide: for small-scale social research projects. McGraw-Hill Education (UK).

Du Plessis, L., Saayman, M., \& Potgieter, M. (2014). Key success factors in managing a visitors' experience at a South African international airport. Journal of Contemporary Management, 11(1): 510-533.

Dusick, D., (2011). Writing the methodology section. Retrieved from: http://www.bold-ed.com/ch3.htm. Accessed [12/02/2017].

Dwyer, L., Pham, T., Forsyth, P., \& Spurr, R. (2014). Destination Marketing of Australia Return on Investment. Journal of Travel Research, 53(3): 281-295.

Eggert, A., \& Ulaga, W. (2002). Customer perceived value: a substitute for satisfaction in business markets?. Journal of Business \& industrial marketing, 17(2/3): 107-118.

Eiglier, P., \& Langeard, E. (1987). Servuction, 6eme ed. Ediscience, Paris.

Ekinci, Y., Sirakaya-Turk, E., \& Baloglu, S. (2007). Host image and destination personality. Tourism Analysis, 12(5-6): 433-446.

Eusébio, C., \& Vieira, A. L. (2013). Destination attributes' evaluation, satisfaction and behavioural intentions: a structural modelling approach. International Journal of Tourism Research, 15(1): 66-80.

Florida, R., Mellander, C., \& Holgersson, T. (2015). Up in the air: The role of airports for regional economic development. The annals of regional science, 54(1): 197-214.

Fraering, M., \& Minor, M. S. (2006). Sense of community: An exploratory study of US consumers of financial services. International Journal of Bank Marketing, 24(5): 284-306.

Hair, J.F., Anderson, R.E, Tatham, R.L. \& Black, W.C. (2006), Multivariate data analysis, 6th edition, London: Prentice-Hall.

Halpern, N., \& Graham, A. (2015). Airport route development: A survey of current practice. Tourism Management, 46:213-221.

Han, H., Kim, Y., \& Kim, E. K. (2011). Cognitive, affective, conative, and action loyalty: Testing the impact of inertia. International Journal of Hospitality Management, 30(4): 1008-1019.

Hooper, D., Coughlan, J., \& Mullen, M. (2008). Structural equation modelling: Guidelines for determining model fit. Articles, 2.

Hosany, S., \& Gilbert, D. (2010). Measuring tourists' emotional experiences toward hedonic holiday destinations. Journal of Travel Research, 49(4): 513-526.

Hyun, M. Y., \& O'Keefe, R. M. (2012). Virtual destination image: Testing a telepresence model. Journal of Business Research, 65(1): 29-35.

Jarach, D. (2001). The evolution of airport management practices: towards a multi-point, multi-service, marketing-driven firm. Journal of air transport management, 7(2): 119-125.

Jeuring, J. H. (2016). Discursive contradictions in regional tourism marketing strategies: The case of Fryslân, The Netherlands. Journal of Destination Marketing \& Management, 5(2): 65-75.

Josiassen, A., Assaf, A. G., Woo, L., \& Kock, F. (2015). The Imagery-Image Duality Model An Integrative Review and Advocating for Improved Delimitation of Concepts. Journal of Travel Research, 1-15

Kavaratzis, M. (2012). From "necessary evil” to necessity: stakeholders' involvement in place branding. Journal of Place Management and Development, 5(1): 7-19

Law, A., De Lacy, T., Lipman, G., \& Jiang, M. (2016). Transitioning to a green economy: the case of tourism in Bali, Indonesia. Journal of Cleaner Production, 111: 295-305.

Lin, I. Y. (2004). Evaluating a servicescape: the effect of cognition and emotion. International Journal of Hospitality Management, 23(2): 163-178

Lopes, S. D. F. (2011). Destination image: Origins, developments and implications. PASOS. Revista de Turismo Patrimonio Cultural, 9(2): 305-315.

Mason, P. (2015). Tourism impacts, planning and management. Routledge.

Matlovičová, K., \& Husárová, M. (2017). Heritage Marketing a Možnosti Jeho Využitia Pri Rozvoji Turistickej Destinácie Prípadová Štúdia Hradu Čičva/Potential Of The Heritage Marketing In Tourist Destinations Development Cičva Castle Ruins Case Study. Folia Geographica, 59(1), 5-35

Matlovičová, K., \& Kormaníková J. (2014). City Brand-Image Associations Detection. Case Study of Prague. SGEM International Multidisciplinary Scientific Conferences on Social Sciences and Arts, SGEM 2014, Psychology \& Psychiatry, Sociology \& Healthcare, Education, Conference Proceedings, Volume II., Sociology and Healthcare, Albena, Bulgaria, ISBN 978-619-7105-23-0, ISSN 2367-5659, pp. 139-146

Matos, N., Mendes, J., \& Valle, P. O. D. (2012). Revisiting the destination image construct through a conceptual model. Dos Algarves: A multidisciplinar e-journal, 21: 101-117. 
Martin-Cejas, R. R. (2006). Tourism service quality begins at the airport. Tourism Management, 27(5): 874-877.

Maziriri, E. T., Lose, T., \& Madinga, W. (2016). The Influence of Relationship Proneness on Relationship Satisfaction and Relationship Commitment: Rapport Building between Domestic Tourists and Small Tourism Enterprises within the Cape Town Metropolitan Area of South Africa. Acta Universitatis Danubius. Economica, 13(1): 173-186.

McDonald, R. P., \& Ho, M. H. R. (2002). Principles and practice in reporting structural equation analyses. Psychological methods, 7(1), 64-82

Minoli, D. M., Goode, M. M., \& Smith, M. T. (2015). Are eco labels profitably employed in sustainable tourism? A case study on Audubon Certified Golf Resorts. Tourism Management Perspectives, 16: 207-216.

Mohammed, B. B., Hairul, N. I., Dalil, M., \& Kawu, A. (2014). Moderating role of affective destination image on the relationship between tourists satisfaction and behavioural intention: evidence from Obudu Mountai Resort. Journal of Environment and Earth Science, 4(4): 47-6o.

Moscardo, G., \& Murphy, L. (2016). Using destination community wellbeing to assess tourist markets: A case study of Magnetic Island, Australia. Journal of Destination Marketing \& Management, 5(1): 55-64.

Nicoletta, R., \& Servidio, R. (2012). Tourists' opinions and their selection of tourism destination images: An affective and motivational evaluation. Tourism Management Perspectives, 4: 19-27.

Nusair, K., \& Hua, N. (2010). Comparative assessment of structural equation modeling and multiple regression research methodologies: E-commerce context. Tourism Management, 31(3): 314-324.

Pike, S., \& Bianchi, C. (2016). Destination brand equity for Australia: testing a model of CBBE in short-haul and long-haul markets. Journal of Hospitality \& Tourism Research, 40(1): 114-134.

Pike, S., \& Page, S. J. (2014). Destination Marketing Organizations and destination marketing: A narrative analysis of the literature. Tourism Management, 41: 202-227.

Prayag, G., \& Ryan, C. (2012). Antecedents of tourists' loyalty to Mauritius: The role and influence of destination image, place attachment, personal involvement, and satisfaction. Journal of Travel Research, 51(3): 342-356.

Pyke, S., Hartwell, H., Blake, A., \& Hemingway, A. (2016). Exploring well-being as a tourism product resource. Tourism Management, 55: 94-105.

Qu, H., Kim, L. H., \& Im, H. H. (2011). A model of destination branding: Integrating the concepts of the branding and destination image. Tourism management, 32(3): 465-476.

Rajesh, R. (2013). Impact of tourist perceptions, destination image and tourist satisfaction on destination loyalty: a conceptual model. Pasos: Revista de turismo y patrimonio cultural, 11(3): 67-78.

Ryu, K., Lee, H. R., \& Gon Kim, W. (2012). The influence of the quality of the physical environment, food, and service on restaurant image, customer perceived value, customer satisfaction, and behavioral intentions. International Journal of Contemporary Hospitality Management, 24(2): 200-223.

Sharifsamet, S., Jin, H. S., \& Martin, B. (2020). Marketing destinations: the impact of destination personality on consumer attitude. Journal of Strategic Marketing, 28(1), 60-69.

Stepchenkova, S., \& Mills, J. E. (2010). Destination image: A meta-analysis of 2000-2007 research. Journal of Hospitality Marketing \& Management, 19(6): 575-609.

Stylos, N., Vassiliadis, C. A., Bellou, V., \& Andronikidis, A. (2016). Destination images, holistic images and personal normative beliefs: Predictors of intention to revisit a destination. Tourism Management, 53: 40-60.

Suárez-Alemán, A., \& Jiménez, J. L. (2016). Quality assessment of airport performance from the passengers' perspective. Research in Transportation Business \& Management, 20: 13-19.

Sung Moon, K., Kim, M., Jae Ko, Y., Connaughton, D. P., \& Hak Lee, J. (2011). The influence of consumer's event quality perception on destination image. Managing Service Quality: An International Journal, 21(3): 287-303.

VisitBritain: Marketing Britain overseas and developing the visitor economy (2014) (online). Available from: http://www.visitbritain.org/ Accessed 10/02/17.

Visser, G., \& Hoogendoorn, G. (2011). Current paths in South African tourism research. Tourism Review International, 15(1-2): 5-20.

Vogt, C., Jordan, E., Grewe, N., \& Kruger, L. (2016). Collaborative tourism planning and subjective well-being in a small island destination. Journal of destination marketing \& management, 5(1), 36-43.

Xie, K. L., \& Lee, J. S. (2013). Toward the perspective of cognitive destination image and destination personality: The case of Beijing. Journal of travel \& tourism marketing, 3o(6), 538-556.

*** South Africa Tourism Review (2015). Report of the Expert Panel (June 2015). Retrieved from http://www.southafrica.net/uploads/files/Tenders/SA Tourism Ministerial Review Report - June 2015.pdf Accessed 03/03/2016.

*** Statistics South Africa (2016) Statistical Release. Tourism and Migration 2016 Retrieved http://www.statssa.gov.za/publications/Po351/Po351November2017.pdf Accessed (02/08/2017).

*** World Tourism Organisation (2013) Tourism Highlights 2013 Edition. Available at:http:// mkt.unwto.org/publication/unwto-tourism-highlights-2013-editionAccessed 16/06/2016.

Submitted:

22.12.2019
Revised:

26.03.2020
Accepted and published online 02.04.2020 